\title{
On the Conflict and Convergence of Tibetan and English Cultures
}

\author{
Chun Dai*
}

\author{
Sichuan Minzu College, Sichuan, China, 626001 \\ Khams Research Institute of Translation on Minority Cultures \\ *Corresponding author. Email:27275600@qq.com
}

\begin{abstract}
The conflict and convergence of Tibetan and English cultures are two inevitable phenomena in the process of heterogeneous cultural communication. This paper mainly discusses the conflicts of Tibetan and English cultural values, economic and cultural conflicts and thinking patterns. It is pointed out that today, with the constant collision, integration, convergence and reorganization of Tibetan and English cultures, the Convergence of foreign cultures needs to respect the differences of different cultures and promote the cultural identity; We need to strengthen the fine culture of our nation and give prominence to its cultural characteristics; We need to resist "cultural hegemony" and insist on the cultural innovation of our own nation: we need to actively implement the cultural development strategy of "going out" and "bringing in", we need to integrate our outstanding culture into the globalization of world culture, and let Western countries in the current era of cultural globalization, have a comprehensive and profound understanding of the history, culture and Customs of the Tibetan nationality in China.
\end{abstract}

Keywords: Tibetan-english culture, Conflict, Convergence

\section{INTRODUCTION}

As a kind of soft power, culture has become an important standard to measure a country's comprehensive strength. With the advancement of economic globalization and world integration, contact, friction, collision and exchange between Tibetan culture and foreign culture have already broken through and transcended the limitation of region and space. In the face of the tide of cultural globalization and the influx of European and American customs and cultures, how to maintain the diversity of Tibetan customs and culture, how to effectively protect and inherit Tibetan culture, and how to make use of and develop the cultural heritage of Tibetan areas, under the influence of today's multi-values, it has important practical significance. It is of great practical significance and theoretical value for spreading and carrying forward the traditional Tibetan culture and developing the Tibetan cultural industry.

\section{THE CULTURAL CONFLICT BETWEEN TIBETAN AND ENGLISH}

What is culture? In his book Primitive Culture (1871), Taylor states: "the culture is a complex totality of knowledge, it includes knowledge, faith, art, morality, law, custom, and all the abilities and customs that humans have acquired in society." As Comrade Mao Zedong Points Out, "a certain culture is the ideological reflection of the politics and economy of a certain society. As for the new culture, it reflects the new politics and New Economy in ideology and serves the new politics and New Economy" [1]. Culture Shock, on the other hand, was first proposed by the American anthropologist Robert Oberg in 1958. In the process of globalization, the inherent cultural differences among countries, regions and ethnic groups inevitably lead to friction and even confrontation and conflict. However, different ethnic groups are gradually moving towards cultural harmony and common development in the midst of conflict and confrontation. Because culture has its own law of development and evolution, it also has the function and mechanism of self-protection and selfperfection. Therefore, this paper mainly describes the conflict of values, language, economy and culture, as well as the conflict of thinking patterns between Tibetan and English cultures. 


\subsection{The Conflict Between Tibetan and English Cultural Values}

In the long course of history, different races have different social experiences to themselves and the world outside themselves, forming different values and beliefs, which leads to differences in cultural values. Both geographically and culturally, Tibetan-English culture belongs to two different camps. Under the background of the present age, the western and other ethnic groups represented by the United States inevitably have differences or conflicts in their cultural values when they communicate with Tibetan nationality. Because any social group has their own culture, have the common social value of community members, that is, the cultural identity of social individuals. This cultural identity depends on the historical, regional and national impact on people. In the process of cultural exchange and dissemination, the culture dominated by European and American culture, by virtue of its economic and political advantages, tries to adopt the way of cultural infiltration and erosion, and strongly emphasizes individualism as the ideological basis of European and American values. They value the individual, they focus on the individual, personal first, emphasizing the rights of the individual, it embodies exquisite cultural values of egoism.

The traditional Tibetan cultural values are full of strong religious color and strict moral and ethical requirements, and bravery and heroism and strong national cohesion. And the spiritual pillar of the Tibetan Buddhism has become an important criterion for the way of thinking, making the Buddhist consciousness melt into the national consciousness, and into a solid collective consciousness. And the legend of King Epic of King Gesar also shows the Tibetan people's heroic spirit, tenacious resistance consciousness, martial spirit and strong desire for peace, reflecting the strong and unique Tibetan traditional cultural characteristics. Therefore, the cultural values of Tibetan people are diametrically opposed to egoism and individualistic values of the capitalist ideology of Western, European and American countries. When the native culture contacts with the foreign culture, it is basically measured by the cultural values of the native nation. When such values are impacted or even threatened by the foreign culture, will lead to the outbreak of national, national and even international conflicts [2].

\subsection{Economic and Cultural Conflict Between Tibet and English}

Culture is closely related to economic life. Economic Culture refers to stable beliefs and values formed in economic life, including economic morality, distribution culture, economic laws, economic regulations and various rules and regulations. Although there is no simple and direct logical implication between economy and culture, system and ethics, the ethical dimensions of economic thought and economic system are quite different among different nationalities. The thought of "economic man" has influenced the economic culture of the whole Western world. They generally think that "people's economic activities have rational thinking and always realize the maximization of individual economic benefits".

The Tibetan people on the Qinghai-Tibet Plateau, who lives under extremely harsh natural conditions, formed the feudal serfdom of the politics with religion unity, because of the prevalence of religious culture, have shaped the general concept of economic ethics, which values justice over wealth and commerce over profit. Moreover, Tibetan culture attaches great importance to the relationship between human ethics and morality, and advocates the use of noble moral image and value standard to mold excellent moral character and personality. As early as the Tibet period, the book of questions and answers on the ancient Tibetan language and etiquette in Dunhuang talks about the how to be a man, "The way to be a man is to be just, filial, not angry, grateful, ashamed, cautious and diligent". Therefore, in the traditional Tibetan culture, "attaching importance to justice rather than wealth, and Loyalty, bravery, as a noble virtue" is considered to be of noble character, encouraging people to devote their main energy to the pursuit of Buddhahood while neglecting industrial and commercial production results in a malformations confrontation between morality and economy, benevolence and righteousness and utility. On the other hand, from an economic point of view, Buddhist ethics are paramount, most of the money saved by Tibetans is not used to develop production but spent on religious activities, and this is bound to inhibit the exchange of goods. Thus, it forms a kind of consumption ethics which not only saves but also wastes religion.

However, Western economic and cultural thought that their privilege is "allow me to have, do not allow others to have". The essence of a capitalist economy is a kind of privilege supported by capital, Privilege is attached to capital, and the acquisition of capital is the acquisition of this privilege. Most importantly, in the European and American countries, property and assets are more important than people, which is a consistent feature of European society. Western thoughts of "utilitarianism", "individualism" and "materialism" are essentially different from Tibetan economic and cultural thoughts. With the acceleration of economic exchanges in the world, different economic cultures easily lead to collisions and conflicts between Tibetan and English cultures. 


\subsection{Tibetan-english Conflict of Thought Patterns}

"The mode of thinking is the deep essence of human cultural phenomenon, which is the stable factor behind the cultural phenomenon and plays a dominant role in human cultural behavior" [3]. The mode of national thinking refers to the way and mode of a nation's understanding of the objective world, including its thinking habits, methods and stereotypes [4]. The Tibetan people have lived on the Qinghai-Tibet Plateau for generations, and their natural environment is very bad. They worship nature, plants, animals and souls. They believe that people and nature, people and people, people and societies are integrated, reflecting the Tibetan people's thinking mode of worshiping nature. Secondly, with the participation and improvement of the Tibetan Bon religion mysticism and the traditional way of thinking of nature worship, it forms a special mode of thinking, religious mode of thinking, which holds that Man, as an individual, has an afterlife and eternal life

The thinking mode of Tibetan people with strong religious speculation is in opposition to the thinking mode of individual standards in Western society. Many countries, such as Britain and America, think that nature is the relationship of active utilization and transformation, and establish the philosophical understanding of "the separation of man and nature", that is, the thinking mode of "the separation of thing from itself and the opposition of subject and object". The dichotomy of thing and self is the opposition and separation of subject and object. This philosophical thought emphasizes individual values and interests in social relations. Western culture advocates the individual as the standard and the individual character. The Tibetan culture takes the whole as its orientation, emphasizing the obedience of individuals to nature, to religion, to groups and to collectives. Therefore, the Tibetan and Europe and the United States have two different thinking values of cultural encounter, the emergence of conflict is inevitable

\section{INTEGRATION OF TIBETAN AND ENGLISH CULTURES}

Cultural globalization has brought the development of National Culture to the crossroads, which not only faces the challenge of strong culture and the crisis of being absorbed and dispelled, but also has the opportunity of renewing the pattern of national culture and realizing its new cultural integration. Cultural Integration is an inevitable trend in the process of cultural conflict. In today's world of economic and cultural integration, the integration of Tibetan and English cultures is also in line with the trend of historical development. On the one hand, Tibetan culture will integrate Western culture into its own culture, infuse fresh blood for itself, and add vitality and vitality, so as to better meet its own development needs. On the other hand, the introduction of Tibetan culture into the heterogeneous culture is conducive to the external dissemination of Tibetan culture, and helps European and American countries to better understand and understand Tibetan nationality and Tibetan culture. In this sense, cultural integration is a double-edged sword, with both advantages and disadvantages, the crux of the matter is that in the process of integration of Tibetan culture with European and American culture, How to achieve cultural renewal and integration, and how to maintain the unique Tibetan culture. That is, the "national character" of culture. Only in this way is multi-cultural coexistence possible to achieve a true sense of cultural integration.

\subsection{Respect Cultural Differences and Expand Cultural Identity}

Every culture has its own characteristics, which are the yardstick of the development of cultural existence and the difference from other cultures. Respecting cultural differences and expanding cultural identity is not only a prerequisite for promoting cultural exchange and integration between Tibet and English, but also conducive to international cultural exchanges. Both the theory of Western Cultural Center and the theory of self-ethnocentrism are one-sided cultural views, it needs to be made clear that there are no advantages or disadvantages between different cultural forms, and there is no either or dilemma. The new value orientation of Tibetan English cultural development is pluralistic symbiosis, learning from each other to complement each other, to promote the common prosperity and dissemination of each other's cultures. We should not only see our own strengths, but also appreciate the strengths of others, to look forward to the development prospects of world culture with the tolerance of harmony for beauty. In the light of the differences and diversity of different nationalities and civilizations, support integration rather than conflict, dialogue rather than confrontation, exchange rather than closed, inclusive rather than exclusive attitude, learn from each other, work hand in hand, and develop together.

Therefore, the concept of a harmonious culture of respect for differences and tolerance for diversity is not only the basic principle for promoting the diversity of human civilization and building a harmonious world, but also the ideological basis for enhancing mutual national cultural identity. 


\subsection{Strengthening the Construction of National Excellent Culture and Displaying its Cultural Characteristics}

As a symbol of national soft power, a nation's culture, like military, economic, scientific and technological hard power, is an important part of the country's core competitiveness. Carry forward and inherit the fine national culture, vigorously excavate the characteristic culture of ethnic minorities, the fine essence of ethnic culture, Like Shakespeare's plays, Li Bai's Tang poems and Wu Cheng en's the journey to the west. It is not only the great representative of National Culture, but also the basis of "connecting, harmonizing and innovating all in mankind" [5]. Each nation has its own unique, traditional culture with local characteristics, in the wave of cultural integration of globalization, if we rely on the pure avoidance of cultural collision to maintain national cultural purity efforts are doomed to be futile, the result can only be self-congratulation, it has been excluded from the historical process of the World Cultural Integration, which makes its national culture decline day by day.

Therefore, we should strengthen the construction of our national culture, not only carry forward and inherit the fine traditional culture of our nation, but also carry forward and practice the fine core values of our nation. We should not only let the essence of our national culture go abroad, but also understand and absorb the excellent foreign culture. This is not only an important contribution to the world culture, but also the fundamental to maintain the "national character" of the national culture.

\subsection{Resist "Cultural Hegemony" and Insist on Cultural Innovation}

Cultural hegemony refers to the domination of one class over the ideology and culture of another class by controlling the content of culture and establishing important customs to unify opinions. In the process of spreading and absorbing culture, Tibetan nationality should resist its hegemonic culture, not attach too much importance to western culture, and at the same time absorb Western excellent culture. What is more important to absorb western culture is to look critically at national culture, select its essence, remove its dross, and get rid of the negative and backward things in the national culture. Only by enriching, perfecting and innovating the national culture can we bring out the national splendor in the multi-cultural world trend, realize the modernization of the national culture as soon as possible, and promote the development of the national economy through cultural publicity. In the process of economic globalization and cultural globalization, the innovation of national culture is to absorb foreign things on the basis of analysis, criticism and dialectical synthesis. At the same time, it is necessary to carry forward the national consciousness of the subject, so as to establish a new culture with national characteristics and reflect the spirit of the times.

To sum up, cultural integration is an objective trend in the development of today's culture. Only by actively participating in cultural globalization can any nation create new features of its own national culture in cultural integration, to build a new system of human culture together. We should carry forward the fine traditions of Tibetan culture and draw on the strengths of the various ethnic groups in the world. The Tibetan culture should be innovated in content and form, enhancing cultural competitiveness, effectively resist the impact of foreign bad culture, carrying forward Tibetan traditional culture and vigorously developing Tibetan cultural industry, in the current era of cultural globalization, the Western countries have a comprehensive and profound understanding of the history, culture and customs of China's Tibet.

\section{CONCLUSION}

In short, today is a world of multi-cultural integration, and the development of culture should be the multi-cultural development under the care of global consciousness. As the famous scholar Fei Xiaotong pointed out at the meeting of the International Federation of Anthropology and Ethnology in 2000, "harmony but difference" will be a road that the world's multiculturalism must take. In the exchange of Tibetan and English cultures, we should make cultural preparations, strive to not only adhere to the characteristics and independence of our own culture, but also reasonably draw lessons from and integrate foreign cultures. Integration needs to respect each other's cultural differences, enhance cultural identity, and seek dialogue and communication between heterogeneous cultures. Actively implement the cultural development of strategy "going out" and "bringing in", make different cultures absorb and integrate each other, and promote the continuous progress of human civilization.

\section{ACKNOWLEDGMENTS}

This research is financially supported by Sichuan Minzu College Project "A comparative study of Tibetan and English taboo culture" (No:XYZB19011SB). And "A comparative study of Tibetan, English and auspicious culture from the perspective of cultural anthropology" (No: XYZB18006SA ).

\section{REFERENCES}

[1] Mao Zedong's Anthology (Vol.2) [M]. BEIJING: People's Publishing House. 1991 p209-214 
[2] Xie Xi. On culture and construction of harmonious world [J]. Theory monthly. 2008(06) p89-94

[3] Zhang Zhongli, Zong Wenju. Introduction to Chinese and Western culture [M]. Tianjin: Tianjin University Press, 2002 p152-160
[4] Peng Yingquan. A restricted view on traditional Tibetan thinking mode [J]. Chinese Tibetology. 1993(02). P114-118

[5] Clode. Delmar. European civilization [M]. People's Publishing House. 1988 P237-248. 